\title{
Seed dormancy, germination and seedling characteristics of Elaeocarpus prunifolius Wall. ex Müll. Berol.: a threatened tree species of north-eastern India
}

\author{
Viheno Iralu ${ }^{1}$ and Krishna Upadhaya ${ }^{2^{*}}$
}

\begin{abstract}
Background: Elaeocarpus prunifolius Wall. ex Müll. Berol. is a threatened tree species of north-eastern India. The present study was undertaken to investigate the type of dormancy prevailing in seeds of $E$. prunifolius, explore seed dormancy breaking techniques and assess seedling fitness.

Methods: Ripe fruits of E. prunifolius were harvested from Jaintia hills, and seeds were subjected to various physical, manual and chemical treatments. The effect of plant growth regulators, viz gibberellic acid $\left(\mathrm{GA}_{3}\right)$ and potassium nitrate $\left(\mathrm{KNO}_{3}\right)$, were tested. Seedling vigour and survival based on seed weight were examined.

Results: Germination took 6 months to initiate after seed dispersal and natural germination percentage of fresh seeds was $24 \%$. Physical pre-germination treatments such as surface and acid scarification failed to overcome dormancy. Cracked seeds promoted germination (46\%) with a mean germination time of 146 days (time to 50\% germination, $T_{50}=144$ days). Among the $\mathrm{GA}_{3}$ treatments, split seeds treated with $\mathrm{GA}_{3}\left(3000 \mathrm{mg} / \mathrm{L}^{-1}\right)$ yielded the highest germination (24\%) with a $T_{50}$ of 55 days whereas $\mathrm{KNO}_{3}$ did not promote germination. A combination of $\mathrm{GA}_{3}$ and $\mathrm{KNO}_{3}$, however, increased the germination to $31 \%$. Between the seed weight classes, the highest percentage of germination was observed in heavy seeds (25\%) and the lowest in light seeds (20\%). There was no significant variation between seed weight and germination time $(p>0.05)$. Seed weight had a significant effect on the shoot height, number of leaves and dry weight of seedlings $(p<0.05)$.

Conclusion: Based on the seed tests, E. prunifolius seeds exhibits 'combined' dormancy (physical and physiological) as splitting seed coat and application of $\mathrm{GA}_{3}$ effectively broke dormancy. Splitting the seed coat is a cost-effective method for accelerating germination of seeds. Heavy-weight seeds produced better performing seedlings compared to their counterparts which may be viewed as an important reproductive strategy of the species.
\end{abstract}

Keywords: Conservation, Elaeocarpus, Germination, Seedling growth, Threatened

\section{Background}

In recent years, studies on germination have emerged as an important tool for conservation of many species. Such studies aid understanding of natural regeneration processes as well as identifying possible causes of species decline, persistence or spread in changing landscapes and their response to global climate change (Schütz

\footnotetext{
* Correspondence: upkri@yahoo.com

${ }^{2}$ Department of Basic Sciences and Social Sciences, School of Technology,

North-Eastern Hill University, Shillong 793 022, India

Full list of author information is available at the end of the article
}

2000; Gill et al. 2013; Tanaka-Oda et al. 2017). Thus, such studies enable the development of suitable protocols for species conservation and management.

The genus Elaeocarpus have ca. 360 species distributed across East Asia, Australia, Malaysia and the Pacific Islands. The International Union for Conservation of Nature and Natural Resources (IUCN) have identified 38 Elaeocarpus species under various threat categories. Of these, 3 species are critically endangered, 4 endangered, 20 vulnerable, 2 near threatened, 8 conservation dependent and 1 data deficient (IUCN 2017). In India, 
30 species occur (Murti 1993a, b), the majority of which are confined to the northeast (Assam, Arunachal Pradesh, Sikkim, Manipur, Meghalaya, Mizoram, Nagaland, Tripura) and south (Tamil Nadu and Kerela) India (Khan et al. 2003; Singh et al. 2013). Out of the six threatened Elaeocarpus species reported from the country, one species (E. gaussenii Weibel) is critically endangered and one endangered (E. blascoi Weibel), three are Vulnerable (viz. E. prunifolius Wall. ex Müll. Berol, E. recurvatus Corner and E. venustus Bedd.) and one (E. munroii Mast.) falls under lower risk/near threatened category. Of these, E. prunifolius is restricted to north-eastern India and the others are confined to southern India.

Research on Elaeocarpus species has gained momentum with the discovery of indolizidine alkaloid compounds in members such as E. fuscoides Knuth., E. grandis F. Muell., E. polydactylus Schltr. and E. densiflorus Knuth (Katavic 2005) for their potential treatment of diseases such as AIDS, diabetes and cancer (Wiart 2006). In addition, fruits of species, viz E. floribundus Blume, E. lanceifolius Roxb., E. braceanus Watt ex C.B. Clarke and E. sikkimensis Mast, are edible (Andola et al. 2011; Das 2014) and species such as E. grandis, E. ruminatus F.Muell., E. foviolatus F. Muell. and E. coorangooloo J.F. Bailey \& C.T. White are known for their good timber value (Bristow et al. 2005).

Elaeocarpus prunifolius is a middle-sized tree that attains a height of ca. $20 \mathrm{~m}$ at maturity (Nayar and Sastry 1990). The phenological calendar of the species is presented in Table 1. The inflorescences are $3-9 \mathrm{~cm}$ long, and the flowers are pale yellow in colour. The ovoid fruits range from 0.8 to $1.2 \mathrm{~cm}$ in diameter. They change from green to bluish-black on maturation. There is only one seed per endocarp. The ripe fleshy mesocarp is predated by worms, insects and birds, and seeds are predated by small rodents, thus, dispersing the seeds in the process (epizoochory) (field observation).

Elaeocarpus prunifolius is a rare and threatened tree species distributed in the state of Manipur and Meghalaya in India and Bangladesh (Murti 1993a, b; World Conservation Monitoring Centre 1998). In Meghalaya, the species is restricted to fragmented pockets of sub-tropical broad-leaved forests with only a few matured individuals (Walter and Gillett 1998; Nayar and Sastry 1990). The species is on the verge of extinction due to habitat degradation (Jain and Rao 1983; Haridasan and Rao 1985), which is further exacerbated by its on-going exploitation for timber by local communities (Nayar and Sastry 1990). The fruits of the species are also edible.

Propagation of Elaeocarpus species from seed is challenging, as the seeds exhibit dormancy (Khan et al. 2003). The fruits of E. prunifolius mature in early September and remain dormant throughout the winter (November-February). The seeds germinate in April with the onset of rain so moisture may be a requirement for germination. The inherent stony endocarp in many members of the genus seems to be a plausible factor for poor germination (Bhuyan et al. 2002; Khan et al. 2003; Ramasubbu and Irudhyaraj 2016). Some studies have revealed low (1-3\%) and erratic seed germination in Elaeocarpus ganitrus Roxb. ex G.Don (Khan et al. 2003) and E. japonicus Siebold (Yang et al. 2001). Natural regeneration of the threatened $E$. blascoi was only $5 \%$ in the wild (Ramasubbu and Irudhyaraj 2016) while in $E$. venustus, E. serratus L and E. williamsianus Guymer, there was no germination (Saravanan et al. 2011; Dahanayake et al. 2013; Rossetto et al. 2004). Contrastingly, some species such as $E$. floribundus had fairly high germination (47\%) (Das 2014). However, there is a dearth of knowledge (particularly on germination) of threatened species often targeted for conservation (Baskin and Baskin 2001). Khan et al. (2003) studied the germination capacity of E. ganitrus by subjecting the seeds to various treatments and found that seeds cracked with a vice resulted in highest germination percentage $(40 \%)$ followed by seeds soaked in hot water for $24 \mathrm{~h}$ and seeds fermented for 20 days (37\%). A mixture of silt and sand media resulted in $40 \%$ germination in $E$. venustus whereas seeds sown in a media of sand, silt and cow dung germinated to about 8\% (Irwin et al. 2013). In E. serratus, seeds treated with $50 \% \mathrm{HNO}_{3}$ germinated to $15 \%$ (Dahanayake et al. 2013). However, there is lack of information on the regeneration capacity of $E$. prunifolius. The poor regeneration of the species in nature could be due to

Table 1 Phenological calendar of E. prunifolius

\begin{tabular}{|c|c|c|c|c|c|c|c|c|c|c|c|c|}
\hline \multirow{2}{*}{$\begin{array}{c}\text { Phenological } \\
\text { events }\end{array}$} & \multicolumn{12}{|c|}{ Months } \\
\hline & J & $\mathrm{F}$ & $\mathrm{M}$ & A & $M$ & $\mathrm{~J}$ & $\mathrm{~J}$ & A & $\mathrm{S}$ & $\mathrm{O}$ & $\mathrm{N}$ & $\mathrm{D}$ \\
\hline LF & & & & & & & & & & & & \\
\hline LM & & & & & & & & & & & & \\
\hline LFA & & & & & & & & & & & & \\
\hline $\mathrm{FL}$ & & & & & & & & & & & & \\
\hline FR & & & & & & & & & & & & \\
\hline FM & & & & & & & & & & & & \\
\hline
\end{tabular}


hard seed coat and/or prolonged dormancy period. The results presented here form part of a larger study to assess the causes of the species rarity in nature by understanding the species phenology, mode of dispersion, predation, seed physiology, germination pattern, seedling characteristics and factors debilitating seedling establishment. The objectives of the current work were to: (i) understand the type of dormancy present in the seeds of E. prunifolius by subjecting the seeds to a set of physical and chemical treatments; (ii) test if total germination and germination rate were influenced by seed weight; and (iii) examine if the seedling growth and survival were influenced by seed weight. The results are discussed in relation to possible factors responsible for low recruitment of this species in nature.

\section{Materials and methods}

\section{Seed source}

Ripe fruits of $E$. prunifolius were harvested during mid-September 2013 from Jarain $\left(25^{\circ} 19.05^{\prime} \mathrm{N}, 92^{\circ}\right.$ $08.34^{\prime} \mathrm{E}$, alt $1200 \mathrm{~m}$ asl), the known location of the species in Meghalaya, Northeast India (Haridasan and Rao 1985). As the species is rare, all mature trees were marked wherever encountered and monitored for fruit maturation. Fruits were collected randomly from ten randomly selected trees and bulked together to form a composite sample (ca. 4500 fruits). The fruits were brought to the laboratory and soaked in normal tap water $\left(18^{\circ} \mathrm{C} \pm 1^{\circ} \mathrm{C}\right.$ for $\left.24 \mathrm{~h}\right)$ to soften the pulp and also to separate healthy seeds from damaged ones (Pipinis et al. 2011). Empty or damaged seeds are lighter and float to the surface and were thus separated from healthy seeds. The fruits were hand crushed and the seeds collected. The seeds were washed thoroughly in running water to remove any adhering substance from the endocarp and disinfected in $0.2 \%$ potassium permanganate $\left(\mathrm{KMnO}_{4}\right)$ solution for $2 \mathrm{~h}$ following the method of $\mathrm{Zuo}$ (1994). The seeds were placed on paper to remove excess moisture and were subjected to various dormancy-breaking treatments within 5 days of seed collection. The remaining seeds were stored in an airtight container filled with a substrate (moist sand) and stored at a constant temperature of $5{ }^{\circ} \mathrm{C}\left( \pm 1^{\circ} \mathrm{C}\right)$ in a refrigerator for further studies.

\section{Water imbibition test}

Twenty-five seeds were cracked with a vice, and the initial weight of each seed was measured. The weights of 25 uncracked seeds were also determined. Both sets of seed were then placed on Petri dishes $(90 \mathrm{~mm} \times 20 \mathrm{~mm}$ ) lined with moist cotton and kept covered under identical laboratory conditions. Each seed was reweighed after 2, $4,6,8,10,20,30$ and $40 \mathrm{~h}$, and the percentage change in mass was averaged from the 25 seeds from each set.

\section{Seed treatments}

(a) Seed coat impermeability is often associated with the presence of impermeable palisade layers of lignified cells (Vazquez-Yanes and Perez-Garcia 1976). Therefore, the following physical or chemical treatments were applied in an attempt to disrupt the seed coat. For each experiment, three replicates of 50 seeds (irrespective of weight) were maintained. Seeds were:

1a. Soaked in cool water $\left(20^{\circ} \mathrm{C}\right)$ for $24 \mathrm{~h}$

2a. Soaked in hot water $\left(80^{\circ} \mathrm{C}\right)$ for $24 \mathrm{~h}$ till the water cooled

3a. Soaked in boiling water $\left(5 \mathrm{~min}\right.$ in $100^{\circ} \mathrm{C}$ and immediately transferred to cold water) for $24 \mathrm{~h}$ 4 a. Scarified by rubbing near the micropyle with sandpaper

5a. Cracked lengthwise with a vice 6a. Scarified near the micropyle using sandpaper and soaked in warm water $\left(45^{\circ} \mathrm{C}\right)$ for $2 \mathrm{~h}$

7a. Soaked in $95 \% \mathrm{H}_{2} \mathrm{SO}_{4}$ for $5 \mathrm{~min}$

8a. Soaked in $95 \% \mathrm{H}_{2} \mathrm{SO}_{4}$ for $10 \mathrm{~min}$

9a. Soaked in $95 \% \mathrm{H}_{2} \mathrm{SO}_{4}$ for $15 \mathrm{~min}$

10a. Soaked in $95 \% \mathrm{H}_{2} \mathrm{SO}_{4}$ for $20 \mathrm{~min}$

11a. A control was maintained by sowing seeds (also irrespective of seed weight) without any of the above-mentioned treatments.

The treated seeds were transferred to plastic trays filled with a mixture of garden soil and sand in the ratio of 3:1. Each tray was labelled and kept under laboratory conditions having an average temperature of $24\left( \pm 1{ }^{\circ} \mathrm{C}\right)$ and light $(>700 \mathrm{~lx})$ duration of $8 \mathrm{~h}$. The trays were watered at 3-day intervals and monitored for germination for a period of 12 months.

(b) The effect of plant growth regulators (PGRs) on breaking seed dormancy and the rate of germination was examined by performing the following tests on seeds cracked lengthwise. Three replicates of 25 seeds were maintained for each treatment. Cracked seeds were:

1b. Soaked in $200 \mathrm{mg} \mathrm{L}^{-1}$ gibberellic acid $\left(\mathrm{GA}_{3}\right)$ for $48 \mathrm{~h}$

2b. Soaked in $500 \mathrm{mg} \mathrm{L}^{-1}$ gibberellic acid $\left(\mathrm{GA}_{3}\right)$ for $48 \mathrm{~h}$

3b. Soaked in $1000 \mathrm{mg} \mathrm{L}^{-1}$ gibberellic acid $\left(\mathrm{GA}_{3}\right)$ for $48 \mathrm{~h}$ 4b. Soaked in $2000 \mathrm{mg} \mathrm{L}^{-1}$ gibberellic acid $\left(\mathrm{GA}_{3}\right)$ for $48 \mathrm{~h}$

5b. Soaked in $3000 \mathrm{mg} \mathrm{L}^{-1}$ gibberellic acid $\left(\mathrm{GA}_{3}\right)$ for $48 \mathrm{~h}$

6b. Soaked in $0.5 \%$ potassium nitrate $\left(\mathrm{KNO}_{3}\right)$ for $48 \mathrm{~h}$ 
7b. Soaked in $1 \% \mathrm{KNO}_{3}$ for $48 \mathrm{~h}$

8b. Soaked in $1.5 \% \mathrm{KNO}_{3}$ for $48 \mathrm{~h}$

9b. Soaked in $2 \% \mathrm{KNO}_{3}$ for $48 \mathrm{~h}$

10b. Soaked in $\mathrm{GA}_{3}$ solution $\left(200 \mathrm{mg} \mathrm{L}^{-1}\right.$ ) for 48

$h$ and transferred to $0.5 \% \mathrm{KNO}_{3}$ solution for another $48 \mathrm{~h}$

11b. Soaked in $\mathrm{GA}_{3}$ solution $\left(500 \mathrm{mg} \mathrm{L}^{-1}\right)$ for 48

$\mathrm{h}$ and transferred to $1 \% \mathrm{KNO}_{3}$ solution for

another $48 \mathrm{~h}$

12b. Soaked in distilled water for $48 \mathrm{~h}$

The control and treated seeds were placed in Petri dishes $(90 \mathrm{~mm} \times 20 \mathrm{~mm})$ lined with moist filter paper and transferred to growth chambers fitted with an LED light source (>4000 lx) with a photoperiod of $8 \mathrm{~h}$. A constant temperature of $25^{\circ} \mathrm{C}\left( \pm 1^{\circ} \mathrm{C}\right)$ was maintained for germination. The germination of the seeds in the growth chambers was monitored at $3 \mathrm{~d}$ intervals for a period of 4 months.

\section{Seed viability}

One hundred and fifty untreated seeds were randomly selected from those stored at $5{ }^{\circ} \mathrm{C}$ for 12 months. Each seed was cracked lengthwise and the embryo excised. Each embryo was tested for viability following the tetrazolium assay of Wang et al. (2005). The presence of living cells in the seeds converts the TTZ (2,3,5 triphenyl tetrazolium chloride) to formazan (red colour) through the hydrogen transfer reaction catalysed by the cellular dehydrogenase, thus, staining the viable seeds red.

\section{Seed germination and seedling growth}

A subsample of 1500 seeds was used to examine the effect of seed weight on germination and seedling growth. Each seed was examined by the floatation method and 60 seeds were found to be damaged. The remaining 1440 healthy seeds were weighed individually. The number of seeds in each of three weight categories (light (< $320 \mathrm{mg}$ ), intermediate (320-480 mg) and heavy (> 480 $\mathrm{mg})$ ) was determined. Seeds from each category were sown under laboratory conditions in plastic trays $(26 \mathrm{~cm}$ diameter, $8 \mathrm{~cm}$ height) within 10 days from the time of seed collection. A mixture of garden soil and sand media in the ratio of 3:1 was used for planting. Twenty-five seeds were sown per tray. Germination was recorded at 3 -day intervals up to 6 months and weekly up to 12 months. The number of germinated seeds was recorded on each occasion. Seeds were considered germinated when the radicles protruded out of the soil surface.

Germinated seedlings (about 2 months old) were transplanted into $20 \times 17 \mathrm{~cm}$ poly bags and transferred to the net house during May 2014. The moisture level was maintained by watering every 3 days. Seedling survival and growth were monitored for a period of 12 months after transplantation. To assess the effect of light on seedling growth, a threefold contrast in light level was created by covering the net houses with an increasing layer of shade netting. Each extra layer intercepted an additional 25\% (approximately) of the incoming radiation, thus, creating three light regimes of approximately $70-75 \%\left(16 \pm 1.8 \mathrm{~mol} \mathrm{~m}^{-2} \mathrm{day}^{-1}\right), 25-30 \% \quad(4 \pm 0.46 \mathrm{~mol}$ $\mathrm{m}^{-2}$ day $\left.^{-1}\right)$ and $5-10 \%\left(1 \pm 0.05 \mathrm{~mol} \mathrm{~m}^{-2}\right.$ day $\left.^{-1}\right)$ designated as high, intermediate and low light treatments respectively. Light intensity was measured with digital lux meter (Lutron LX-101A) at three different times during the day (9.00 a.m., 12 noon and 3 p.m.) each month and the seasonal means were calculated.

To assess the effect of seed weight and light on growth performance of the seedlings, ten randomly selected seedlings under each weight category and light condition were harvested after one year of transplantation (May 2015) and their shoot height, root length, the number of leaves, leaf area and dry matter yield were determined. The leaf area was measured using a leaf area meter (LICOR, Lincoln). Dry matter yield was determined by drying the plant material in an oven at $80{ }^{\circ} \mathrm{C}$ for $24 \mathrm{~h}$ to a constant weight.

Germination percentage was calculated using the formula:

$$
G(\%)=\frac{n}{N} \times 100
$$

where $\mathrm{n}$ is the number of germinated seeds and $\mathrm{N}$ is the total number of seeds. The method of Coolbear et al. (1984) further modified by Farooq et al. (2006) was used to calculate the time to reach $50 \%$ germination $\left(T_{50}\right)$ :

$$
T_{50}=t_{1}+\left[\left(\frac{N}{2}-n_{i}\right)\left(t_{j}-t_{i}\right)\right] / n_{j}-n_{i},
$$

where $N$ is the final number of germinated seeds, $n_{i}$ and $n_{j}$ are the cumulative numbers of seeds germinated at times $t_{i}$ and $t_{j}$, respectively, when $n_{i}<N / 2<n_{j}$.

\section{Seed coat thickness}

Seed-coat thickness was determined in each seed weight category to test the assumption that: (i) heavier seeds had thicker coats; and (ii) thicker seed coats may delay germination. Seeds were cut across and seed coat thickness was measured using a calliper and the values averaged. For each weight category, 30 seeds each were considered.

\section{Data analysis}

To determine the effect of different treatments on germination, analysis of variance (ANOVA) was used followed by Tukey and Scheffe's least significant difference $(p<0.05)$. Assumptions of ANOVA were met 
through a test for normality of variables (Shapiro-Wilk test) and homogeneity of group variances (Levene's test). The relation between seed weight and seedling growth was analysed by regression. All the statistical analysis was performed using SPSS software (version 20).

\section{Results}

\section{Imbibition test}

The initial moisture content of scarified seeds was $10.6 \%$ and non-scarified seeds was $10.8 \%$. After $40 \mathrm{~h}$, both sets of seeds had a moisture content of $11.2 \%$ so the increase in the mass of scarified and non-scarified seeds was $6 \%$ and $4 \%$ respectively. This difference was not significant $(p>0.05)$ so uncracked seeds imbibe water at a similar rate as cracked seeds.

\section{Dormancy-breaking treatments}

Physical and chemical treatments 1a - 10a were compared to germination of untreated seeds (11a).

The germination percentage of control seeds was $24 \%$. The mean number of days required for germination of control seeds was $213 \pm 5$ days $\left(T_{50}=174 \pm 9\right.$ days $)$. No germination of seeds occurred after 230 days. Only treatments $1 \mathrm{a}, 5 \mathrm{a}$ and $6 \mathrm{a}$ resulted in any germinated seedlings. Of these, treatment 1a (cold-water soak) reduced germination to $10.67 \%\left(T_{50}=210\right.$ days $)$ compared with the control (24\%) while $14.67 \%$ of seeds $\left(T_{50}=216\right.$ days $)$ germinated following treatment with a combination of scarification and warm water treatment (Treatment 6a). The germination percentage of seeds from these two treatments was significantly lower $(p<0.05)$ than the control. In contrast, $45.83 \%$ of seeds cracked with a vice germinated and this was significantly higher $(p<0.05)$ than for all other treatments. The mean germination time and $T_{50}$ was also significantly reduced under this treatment (146 and 144 days respectively) (Table 2).

Treatments (1b-11b) involving soaking cracked seeds in solutions of various plant growth regulators were compared with germination of cracked seeds soaked in water (Treatment 12b), Table 2. Cracking seeds (Treatment $5 \mathrm{a}$ ) resulted in better germination than no treatment (11a) but soaking seeds in water (Treatment 12b)

Table 2 Germination of E. prunifolius seeds subjected to (a) physical, mechanical and chemical scarification and (b) plant growth regulators

\begin{tabular}{|c|c|c|c|c|}
\hline Treatment No. & Treatment details & Mean germination (days) & Germination (\%) & $T_{50}$ (days) \\
\hline$\overline{1 a}$ & Cold water $\left(20^{\circ} \mathrm{C}\right)$ & $210 \pm 1^{a}$ & $10.67 \pm 1.33^{\mathrm{a}}$ & $210 \pm 2$ \\
\hline $2 a$ & Hot water $\left(80^{\circ} \mathrm{C}\right)$ & 0 & 0 & 0 \\
\hline $3 a$ & Boiling water $\left(100^{\circ} \mathrm{C}\right)$ & 0 & 0 & 0 \\
\hline $4 a$ & Scarification near micropyle & 0 & 0 & 0 \\
\hline $5 a$ & Cracked seeds with vice & $146 \pm 1$ & $45.83 \pm 1$ & $144 \pm 2$ \\
\hline $6 a$ & Scarified+warm water $(2 \mathrm{~h}$ ) & $212 \pm 1^{a}$ & $14.67 \pm 1.33^{\mathrm{a}}$ & $216 \pm 2$ \\
\hline $7 a$ & $95 \% \mathrm{H}_{2} \mathrm{SO}_{4}$ for $5 \mathrm{~min}$ & 0 & 0 & 0 \\
\hline $8 a$ & $95 \% \mathrm{H}_{2} \mathrm{SO}_{4}$ for $10 \mathrm{~min}$ & 0 & 0 & 0 \\
\hline $9 a$ & $95 \% \mathrm{H}_{2} \mathrm{SO}_{4}$ for $15 \mathrm{~min}$ & 0 & 0 & 0 \\
\hline $10 a$ & $95 \% \mathrm{H}_{2} \mathrm{SO}_{4}$ for $20 \mathrm{~min}$ & 0 & 0 & 0 \\
\hline $11 a$ & Untreated control & $213 \pm 5^{a}$ & $24.67 \pm 3$ & $174 \pm 9$ \\
\hline $1 b$ & $200 \mathrm{mg} \mathrm{L}^{-1} \mathrm{GA}_{3}$ & 0 & 0 & 0 \\
\hline $2 b$ & $500 \mathrm{mg} \mathrm{L}^{-1} \mathrm{GA}_{3}$ & $78 \pm 1^{\mathrm{a}}$ & $15.56 \pm 2^{a}$ & $77 \pm 1$ \\
\hline $3 b$ & $1000 \mathrm{mg} \mathrm{L}^{-1} \mathrm{GA}_{3}$ & $63 \pm 1^{b}$ & $17.78 \pm 2^{\text {ad }}$ & $64 \pm 2$ \\
\hline $4 b$ & $2000 \mathrm{mg} \mathrm{L}^{-1} \mathrm{GA}_{3}$ & $70 \pm 2^{c}$ & $20 \pm 0^{\text {ae }}$ & $71 \pm 2$ \\
\hline $5 b$ & $3000 \mathrm{mg} \mathrm{L}^{-1} \mathrm{GA}_{3}$ & $54 \pm 1^{d}$ & $24.44 \pm 2^{\text {ce }}$ & $55 \pm 1$ \\
\hline $6 b$ & $0.5 \% \mathrm{KNO}_{3}$ & 0 & 0 & 0 \\
\hline $7 b$ & $1 \% \mathrm{KNO}_{3}$ & 0 & 0 & 0 \\
\hline $8 b$ & $1.5 \% \mathrm{KNO}_{3}$ & $63 \pm 3^{b}$ & $8.89 \pm 2^{b}$ & $62 \pm 3$ \\
\hline $9 b$ & $2.0 \% \mathrm{KNO}_{3}$ & 0 & 0 & 0 \\
\hline $10 \mathrm{~b}$ & $200 \mathrm{mg} \mathrm{L}^{-1} \mathrm{GA}_{3}+0.5 \% \mathrm{KNO}_{3}$ & $63 \pm 3^{b}$ & $22.22 \pm 2^{\text {de }}$ & $61 \pm 3$ \\
\hline $11 b$ & $500 \mathrm{mg} \mathrm{L}^{-1} \mathrm{GA}_{3}+1 \% \mathrm{KNO}_{3}$ & $56 \pm 1^{\text {de }}$ & $31 \pm 2^{f}$ & $56 \pm 2$ \\
\hline $12 b$ & Water & 0 & 0 & 0 \\
\hline
\end{tabular}

$T_{50}$ : time required to attain $50 \%$ germination, \pm SEM (standard error of mean) 
produced no germination. Seeds treated with $200 \mathrm{mg} \mathrm{L}^{-1}$ $\mathrm{GA}_{3}$ (Treatment $1 \mathrm{~b}$ ) did not germinate either but there was a positive linear relationship $(Y=0.0076 x+4.4304$, $\left.R^{2}=0.726, p=0.03\right)$ between germination percentage and increasing $\mathrm{GA}_{3}$ concentration with a maximum germination of $24.44 \%$ for seeds treated with $3000 \mathrm{mg}$ $\mathrm{L}^{-1} \mathrm{GA}_{3}\left(T_{50}=55\right.$ days $)$, Table 2 . Increasing concentration of $\mathrm{GA}_{3}$ decreased the time required to attain $50 \%$ germination $\left(T_{50}\right)$ (Fig. 1 ), more so than the potted experiments (treatment 1a-11a). No seeds germinated following treatment with $0.5 \%, 1 \%$ or $2 \% \mathrm{KNO}_{3}$ (Treatment $6 \mathrm{~b}, 7 \mathrm{~b}$ and $9 \mathrm{~b}$ ) but, surprisingly, a small percentage of seeds $(8.89 \%)$ did germinate following Treatment $8 \mathrm{~b}\left(1.5 \% \mathrm{KNO}_{3}\right)$. Neither $200 \mathrm{mg} \mathrm{L}^{-1}$ nor $0.5 \% \mathrm{KNO}_{3}$ alone (Treatments $1 \mathrm{~b}$ and $6 \mathrm{~b}$ respectively) produced any germination yet the combination of the two (Treatment $10 \mathrm{~b}$ ) did result in $22 \%$ germination. The highest germination percentage of $31 \%\left(T_{50}=56\right.$ days) was obtained using a combination of $500 \mathrm{mg} \mathrm{L}^{-1}$ $\mathrm{GA}_{3}$ and $1.0 \% \mathrm{KNO}_{3}$. Results from multiple comparison tests between the various treatments showed a significant difference in the mean germination percentage of seeds treated with a combination of 500 $\mathrm{mgL}^{-1} \mathrm{GA}_{3}+1 \% \quad \mathrm{KNO}_{3}$ with all concentrations of $\mathrm{GA}_{3}$ and $\mathrm{KNO}_{3}(p<0.05)$ except for seeds treated in $3000 \mathrm{mg} \mathrm{L}^{-1} \mathrm{GA}_{3}$ and $200 \mathrm{mg} \mathrm{L}^{-1}+0.5 \% \mathrm{KNO}_{3}$.

\section{Seed viability}

Embryos stained with tetrazolium indicated viability. Of the 150 seeds tested, 111 embryos (74\%) were stained. Visual inspection of the embryos showed that they were curved with narrow cotyledons characteristic of $40 \%$ of Malesian Elaeocarpus species (Weibel 1968; Flora Malesiana Symposium 1989).

\section{Seed weight and seedling growth}

Seed weight $(n=1440)$ ranged from 160 to $630 \mathrm{mg}$ (mean weight $385.58 \pm 1.90 \mathrm{mg}$ ). The distribution was normal (Shapiro-Wilk test), with intermediate seeds constituting $74.93 \%$ of the total seed population followed by light and heavy that accounted for $16.31 \%$ and $8.75 \%$ respectively (Table 3). More heavy seeds (24.60\%) germinated than intermediate $(22.80 \%)$ or light seeds (19.57\%), Table 3. There was no significant relationship between the seed weight and germination time $(p>0.05)$. The time to $50 \%$ germination $\left(T_{50}\right)$ was longest in intermediate seed weight (218 days) and shortest for light seeds (188 days) (Table 3 ). One year after transplantation, $100 \%$ of seedlings emerging from heavy- and intermediate-weight seeds had survived but only $85 \%$ of those from light-weight seeds. Seeds $<320 \mathrm{mg}$ had an average coat thickness of $0.66 \mathrm{~mm}$ compared with $1.42 \mathrm{~mm}$ for seeds $>480 \mathrm{mg}$. Light seeds had an average length of $12 \mathrm{~mm}$ whereas seed length in intermediate and heavy seeds measured an average $13 \mathrm{~mm}$ and $15 \mathrm{~mm}$ respectively. Similarly, seed width was lower in light weight seeds $(7 \mathrm{~mm})$ as compared to heavy seeds (8 $\mathrm{mm})$, Table 3.

Significant differences $(p<0.05)$ were observed in the shoot height, leaf area and dry biomass of seedlings emerging from light seeds compared with those of intermediate and heavy seeds (Table 4). However, there was no significant difference between the intermediate and heavy seeds $(p>0.05)$.

Regression analysis showed that seed weight had a positive impact on seedling vigour with heavier seeds producing larger and heavier seedlings (Table 5).

\section{Discussion}

Seeds stored at $5{ }^{\circ} \mathrm{C}$ remained viable even after 12 months of storage indicating 'orthodox' (i.e. will survive

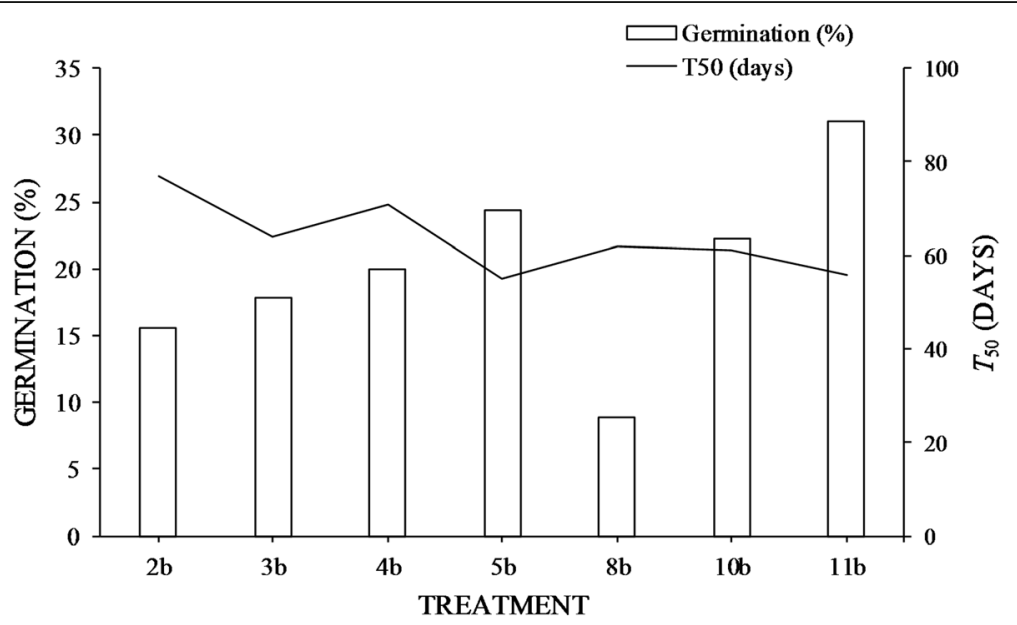

Fig. 1 Mean $\left( \pm\right.$ SEM) germination percentage $(\mathrm{G} \%)$ and time to $50 \%$ germination $\left(T_{50}\right)$ under $\mathrm{GA}_{3}$ and $\mathrm{KNO}_{3}$ treatments at $25^{\circ} \mathrm{C}$. (Treatments: $2 b=500 \mathrm{mg} \mathrm{L}^{-1}, 3 \mathrm{~b}=1000 \mathrm{mg} \mathrm{L}^{-1}, 4 \mathrm{~b}=2000 \mathrm{mg} \mathrm{L}^{-1}, 5 \mathrm{~b}=3000 \mathrm{mg} \mathrm{L}^{-1}, 8 \mathrm{~b}=1.5 \% \mathrm{KNO}_{3}, 10 \mathrm{~b}=200 \mathrm{mg} \mathrm{L}^{-1} \mathrm{GA}_{3}+0.5 \% \mathrm{KNO}_{3}$, $\left.11 \mathrm{~b}=500 \mathrm{mg} \mathrm{L}^{-1} \mathrm{GA}_{3}+1 \% \mathrm{KNO}_{3}\right)$ 
Table 3 Germination characteristics of E. prunifolius seeds

\begin{tabular}{|c|c|c|c|c|}
\hline \multirow[t]{2}{*}{ Parameters } & & \multicolumn{3}{|c|}{ Seed weight class(mg) } \\
\hline & & Light $(<320)$ & Intermediate (320-480) & Heavy $(>480)$ \\
\hline \multicolumn{2}{|c|}{ Number of seeds sown (n) } & 235 & 1079 & 126 \\
\hline \multicolumn{2}{|c|}{ Average seed length (mm) } & $11.92 \pm .064$ & $13.47 \pm .028$ & $14.52 \pm .059$ \\
\hline \multicolumn{2}{|c|}{ Average seed width (mm) } & $6.80 \pm .027$ & $7.37 \pm .017$ & $8.02 \pm .034$ \\
\hline \multicolumn{2}{|c|}{ Number of seeds germinated } & 46 & 246 & 31 \\
\hline \multirow[t]{2}{*}{ Proportion of Seed } & Contribution to total seed lot (\%) & 16.31 & 74.93 & 8.75 \\
\hline & Germination (\%) & $19.57^{a}$ & $22.8^{\mathrm{a}}$ & $24.6^{a}$ \\
\hline \multicolumn{2}{|c|}{ Mean germination (days) } & $211 \pm 4$ & $212 \pm 1$ & $213 \pm 3$ \\
\hline \multicolumn{2}{|l|}{$T_{50}($ days $)$} & $188 \pm 9$ & $218 \pm 7$ & $204 \pm 6$ \\
\hline \multicolumn{2}{|c|}{ Seed coat thickness (mm) } & $0.66 \pm 0.12$ & $1.07 \pm 0.06$ & $1.42 \pm 0.06$ \\
\hline \multicolumn{2}{|c|}{ Weight of cotyledon (g) } & $0.077 \pm 0.005$ & $0.102 \pm 0.002$ & $0.117 \pm 0.002$ \\
\hline
\end{tabular}

Note: For each treatment, means followed by the same letter in each row do not differ significantly at $p<0.05$

drying and/or freezing during ex situ conservation) characteristics (Chin et al. 1989). However, intact untreated seeds took an average of 213 days to germinate under favourable conditions, which clearly indicates the presence of dormancy (Baskin and Baskin 1998, 2004). Physical and mechanical dormancy is the most common inhibitor of germination in many species. Threatened tree species such as Cupressus atlantica (Youssef et al. 2012), Elaeocarpus blascoi Weibel (Ramasubbu and Irudhyaraj 2016) and Intsia bijuga (Colebr.) Kuntze (Thaman et al. 2006) exhibit exogenous dormancy where the hard seed coats inhibit water penetration that is required for embryo growth and development.

Reducing germination time and increasing germination percentage are both important pre-requisites of a successful propagation initiative. Cracked E. prunifolius seeds germinated faster and in greater numbers than intact seeds, as expected by disrupting the hard coat surrounding the seed. Similar results have been reported in E. ganitrus (Khan et al. 2003). However, cracked seeds still remained dormant for ca. 3 months and the germination time decreased further only by soaking in gibberellic acid solution $\left(\geq 500 \mathrm{mg} \mathrm{L}^{-1}\right)$ or a combination of gibberellic acid and potassium nitrate. Similar results have been reported in species like Ramonda serbica Pančić, $R$. nathaliae Pančić \& Petrovič, Magnolia yunnanensis (Hu) Noot. and M. punduana (Hk. $\mathrm{f} \&$ Th.) Figlar (Gashi et al. 2012; Han et al. 2010; Iralu and Upadhaya 2016). The presence of abscisic acid (ABA) in mature seeds has been associated with seed dormancy (Matakiadis et al. 2009; Hilhorst and Karssen 1992), and studies have established that the application of nitrate ions to a germination medium leads to rapid decline of ABA. However, three of the four concentrations of potassium nitrate tested alone in the current study prevented germination. The positive effect of some PGAs in the current study indicates that (in addition to physical dormancy) seeds may also have 'physiological' dormancy also called 'combined' dormancy (Baskin and Baskin 1998; Nikolaeva 1969), which was broken by the

Table 4 Shoot height and root length (cm), number of leaves/plant, leaf area $\left(\mathrm{cm}^{2}\right)$ and dry weight/plant $(\mathrm{g})$ of seedlings of $E$. prunifolius ( \pm SEM, $n=10$ ) in light-, intermediate-and heavy-seed weight classes grown under three different contrasting light regimes after 1 year of transplantation

\begin{tabular}{|c|c|c|c|c|c|c|}
\hline $\begin{array}{l}\text { Day length (h)/light intensity (mol } \\
m^{-2} d^{-1} \text { ) }\end{array}$ & $\begin{array}{l}\text { Seed weight } \\
\text { (mg) }\end{array}$ & $\begin{array}{l}\text { Shoot height } \\
(\mathrm{cm})\end{array}$ & $\begin{array}{l}\text { Root length } \\
(\mathrm{cm})\end{array}$ & $\begin{array}{l}\text { Number of leaves/ } \\
\text { plant }\end{array}$ & $\begin{array}{l}\text { Leaf area/seedling } \\
\left(\mathrm{cm}^{2}\right)\end{array}$ & $\begin{array}{l}\text { Dry weight/plant } \\
\text { (g) }\end{array}$ \\
\hline \multirow[t]{3}{*}{$10 / 16$} & $<320$ & $20.57 \pm .39^{\mathrm{a}}$ & $16.63 \pm 0.54^{a}$ & $7.2 \pm 0.48^{a}$ & $9.93 \pm 0.18^{\mathrm{a}}$ & $0.56 \pm 0.08^{\mathrm{a}}$ \\
\hline & $320-480$ & $39.25 \pm 0.90$ & $26.80 \pm 1.10$ & $15.4 \pm 0.52^{\mathrm{a}}$ & $21.09 \pm 0.69$ & $2.76 \pm 0.67$ \\
\hline & $>480$ & $26.46 \pm 0.17^{\mathrm{a}}$ & $17.28 \pm 0.35^{a}$ & $11.4 \pm 0.39^{\mathrm{a}}$ & $13.72 \pm 0.74^{a}$ & $1.43 \pm 0.33^{a}$ \\
\hline \multirow[t]{3}{*}{$10 / 4$} & $<320$ & $31.27 \pm 1.07$ & $25.84 \pm 2.13^{b}$ & $12.40 \pm 0.25^{b}$ & $15.81 \pm 0.63$ & $1.74 \pm 0.24$ \\
\hline & $320-480$ & $46.68 \pm 2.66^{b}$ & $26.22 \pm 0.72^{b}$ & $15.6 \pm 1.28^{c}$ & $22.61 \pm 1.03^{b}$ & $2.95 \pm 1.12^{\mathrm{b}}$ \\
\hline & $>480$ & $42.81 \pm 0.71^{b}$ & $30.63 \pm 1.42^{b}$ & $13.06 \pm 0.68^{b c}$ & $24.48 \pm 1.37^{b}$ & $3.31 \pm 0.48^{b}$ \\
\hline \multirow[t]{3}{*}{$10 / 1$} & $<320$ & $9.70 \pm 1.18^{c}$ & $5.82 \pm 2.70^{c}$ & $3 \pm 0.40$ & $3.63 \pm 1.15^{c}$ & $0.06 \pm 0.15^{c}$ \\
\hline & $320-480$ & $18.96 \pm 0.42^{d}$ & $21.52 \pm 1.19^{d}$ & $7.4 \pm 0.76^{d}$ & $10.42 \pm 0.83^{d}$ & $0.27 \pm 0.19^{c}$ \\
\hline & $>480$ & $15.15 \pm 0.46^{\mathrm{cd}}$ & $13.80 \pm 1.83^{\mathrm{cd}}$ & $6.8 \pm 0.17^{d}$ & $7.44 \pm 0.53^{\mathrm{cd}}$ & $0.19 \pm 0.22^{c}$ \\
\hline
\end{tabular}


Table 5 Seed weight influence on seedling characteristics in $E$. prunifolius. Regression Eq. $(Y=c+m x)$ for the relationship between initial seed weight $(n=10)$, shoot and root length (cm), number of leaves/plant, leaf area $\left(\mathrm{cm}^{2}\right)$ and dry weight/ plant (g)

\begin{tabular}{llll}
\hline Variables & Regression equation & $r$ & $p$ value \\
\hline Shoot height & $Y=19.722+51.963$ & 0.531 & 0.002 \\
Root length & $Y=16.401+28.830$ & 0.530 & 0.002 \\
Number of leaves/plant & $Y=10.814+7.838$ & 0.313 & 0.091 \\
Leaf area & $Y=6.276+37.577$ & 0.791 & 0.000 \\
Dry biomass & $Y=-0.540+8.284$ & 0.763 & 0.000 \\
\hline
\end{tabular}

Significant at $p<0.05$

application of gibberellic acid (Baskin and Baskin 1998, 2004). Physiological dormancy has also been reported from other species of Elaeocarpus such as E. floribiindus, E. petiolatm and E. stipularis (Ng 1978, 1980; Beniwal and Singh 1989).

The fruits of E. prunifolius mature in early September and remain dormant throughout the winter (NovemberFebruary). The seeds germinate in April with the rise in temperature and onset of rain indicating that these environmental cues may be a requirement for germination. Similar moisture-aided germination has been reported in Prunus jenkinsii Hook. f. \& Th. and other endemic species of the region (Upadhaya et al. 2007; Upadhaya et al. 2017). However, uncracked seeds imbibed only a small amount of water during soaking and this was not improved by pre-cracking the seeds. Soaking either cracked or uncracked seeds in water before sowing might be expected to improve the speed and extent of germination but, surprisingly, resulted in no germination. In contrast, Khan et al. (2003) found that soaking E. ganitrus seeds in hot water for $24 \mathrm{~h}$ then fermenting them for 20 days led to $37 \%$ germination. All the sulphuric acid treatments test in the current study prevented germination of $E$. prunifolius seeds yet $15 \%$ of $E$. serratus seeds treated with $50 \%$ nitric acid germinated (Dahanayake et al. 2013).

Seed-coat impermeability is usually associated with the presence of one or more layers of impermeable palisade layers of lignified cells (Corner 1976; Vazquez-Yanes and Perez-Garcia 1976). However, seed coat thickness did not impede or delay germination as germination percentage was higher in heavy seeds (which had thicker coats) and the mean germination time was not significantly different across the seed weight classes. Similar findings have been observed in Oenothera biennis $\mathrm{L}$ (Gross and Kromer 1986), Diplotaxis erucoides (L.) DC. and D. virgata (Cav.) DC. (Perez-Garcia et al. 1995). Barnett (1997) observed that $69 \%$ of the variation in the speed of germination in five pine species was related to the seed coat. In the present study, germination percentage was positively correlated with seed weight. This finding is similar to that reported in Artocarpus heterophyllus L., Alangium lamarckii Thwaites, Quercus semiserrata Roxb. and other oak species (Khan 2004; Ahirwar 2012; Barik et al. 1996; Bonfil 1998; Tripathi and Khan 1990; Khan and Shankar 2001). Heavy seeds are associated with greater stocks of food and energy reserves and provide readily available energy and resources to stimulate germination (Flint and Palmblad 1978).

The seedlings from heavy seeds survived better and exhibited greater biomass but the amount of heavy seed in the sample tested was low. Similar results have been observed in Quercus species (Tripathi and Khan 1990; Khan and Shankar 2001). The current study was part of a larger project to examine issues with E. prunifolius germination in the wild (data not shown). The main constraint of germination under natural conditions was premature seed fall caused by strong winds and rain. Also, mature fruits were predated by rodents, birds, worms and ants before the seeds germinated. A substantial number of seeds did germinate but, young seedlings suffered mortality due to desiccation during winter and also due to trampling. Similar observations have also been reported in other Elaeocarpus species (Matthew 1999).

\section{Conclusion}

Elaeocarpus prunifolius seed exhibits both physical and physiological dormancy. Splitting the seed coats with a vice is a prerequisite for propagation and is also a cost-effective method. In addition, treating cracked seeds with a combination of $\mathrm{GA}_{3}$ and $\mathrm{KNO}_{3}$ accelerates the germination rate, which may enable mass propagation for reintroduction programmes. Heavy seeds showed better survival and growth than lighter seeds so heavy seeds should be separated out wherever practical and used for propagation.

\section{Abbreviations}

ABA: Abscisic acid; $\mathrm{GA}_{3}$ : Gibberellic acid; $\mathrm{H}_{2} \mathrm{SO}_{4}$ : Sulphuric acid;

$\mathrm{KMnO}_{4}$ : Potassium permanganate; $\mathrm{KNO}_{3}$ : Potassium nitrate; $T_{50}$ : Time to $50 \%$ germination

\section{Acknowledgements}

We thank the Headman of Jarain Village for permitting us to work in the forests. The critical comments received from the two anonymous reviewers are also acknowledged. We also thank the editor for thoroughly editing and improving the manuscript.

\section{Funding}

The first author acknowledges the financial support received from University Grants Commission (UGC) in the form of RGNF-JRF (F1-17.1/2013-14/RGNF2013-14-ST-NAG-43868/ (SA-III/Website). Dated: 06-Feb-2014).

\section{Availability of data and materials}

Not applicable

\section{Authors' contributions}

$\mathrm{VI}$ and $\mathrm{KU}$ conceived and designed the study. Experimental works were carried out by VI. Data analysis was done by KU and manuscript was drafted by $\mathrm{VI}$ and $\mathrm{KU}$. Both authors read and approved the final manuscript. 


\section{Ethics approval and consent to participate}

Not applicable

\section{Consent for publication \\ Not applicable}

\section{Competing interests}

The authors declare that they have no competing interests.

\section{Publisher's Note}

Springer Nature remains neutral with regard to jurisdictional claims in published maps and institutional affiliations.

\section{Author details}

'Department of Environmental Studies, School of Human and Environmental Sciences, North-Eastern Hill University, Shillong 793 022, India. Department of Basic Sciences and Social Sciences, School of Technology, North-Eastern Hill University, Shillong 793 022, India.

Received: 20 December 2017 Accepted: 15 November 2018

Published online: 28 December 2018

\section{References}

Ahirwar, J. R. (2012). Effect of seed size and weight on seed germination of Alangium lamarckii, Akola, India. Research Journal of Recent Sciences, 1, 320-322.

Andola, H. C., Rawal, R. S., \& Bhatt, I. D. (2011). Comparative studies on the nutritive and anti-nutritive properties of fruits in selected Berberis species of West Himalaya, India. Food Research International, 44, 2352-2356.

Barik, S. K., Tripathi, R. S., Pandey, H. N., \& Rao, P. (1996). Tree regeneration in a subtropical humid forest: effect of cultural disturbance on seed production, dispersal and germination. Journal of Applied Ecology, 33, 1551-1560.

Barnett, J. P. (1997). Relating pine seed coat characteristics to speed of germination, geographic variation, and seedling development. Tree Planters Notes, 48(1,2), 38-42.

Baskin, C. C., \& Baskin, J. H. (1998). Seeds. Ecology, biogeography and evolution of dormancy and germination. San Diego: Academic Press.

Baskin, J. M., \& Baskin, C. C. (2001). Seeds. San Diego: Academic Press.

Baskin, J. M., \& Baskin, C. C. (2004). A classification system for seed dormancy. Seed Science Research, 14, 1-16.

Beniwal, B. S., \& Singh, N. B. (1989). Observations on flowering, fruiting and germination behaviours of some useful forest plants of Arunachal Pradesh. Indian Forester, 115, 216-227

Bhuyan, P., Khan, M. L., \& Tripathi, R. S. (2002). Regeneration status and population structure of Rudraksh (Elaeocarpus ganitrus Roxb.) in relation to cultural disturbances in tropical wet evergreen forest of Arunachal Pradesh. Current Science, 83, 1391-1394.

Bonfil, C. (1998). The effects of seed size, cotyledon reserves, and herbivory on seedling survival and growth in Quercus rugosa and Q. laurina (Fagaceae). American Journal of Botany, 85, 79-87.

Bristow, M., Annandale, M., \& Bragg, A. (2005). Growing rainforest timber trees: A farm forestry manual for North Queensland. A report for the RIRDC/Land \& Water Australia/FWPRDC / MDBC Joint Venture Agroforestry Program. RIRDC Publication No. 03/010 RIRDC Project No. DAQ-240A. Wagga Wagga NSW: Rural Industries Research and Development Corporation.

Chin, H. F., Krishnapillay, B., \& Stanwood, P. C. (1989). Seed moisture: recalcitrant vs. orthodox seeds. In P. C. Stanwood \& M. B. McDonald (Eds.), Seed Moisture. CSSA Special Publication no. 14. Madison: Crop Science Society of America.

Coolbear, P., Francis, A., \& Grierson, D. (1984). The effect of low temperature presowing treatment on the germination performance and membrane integrity of artificially aged tomato seeds. Journal of Experimental Botany, 35, 1609-1617.

Corner, E. J. H. (1976). The Seeds of Dicotyledons, Vols. I and II. Cambridge/London/ New York/Melbourne: Cambridge University Press.

Dahanayake, N., Alawathugoda, C. J., \& Ranawake, A. L. (2013). Induce seed germination of Veralu (Elaeocarpus serratus L.). Proceedings of the Second International Symposium on Minor Fruits and Medicinal Plants for Better Lives (2nd ISMF \& MP) (pp. 50-53). Sri Lanka: University of Ruhuna.

Das, N. (2014). The effect of seed sources variation and presowing treatments on the seed germination of Acacia catechu and Elaeocarpus floribundus species in Bangladesh. International Journal of Forestry Research. https://doi.org/10. 1155/2014/984194.
Farooq, M., Basra, S. M. A., Afzal, I., \& Khaliq, A. (2006). Optimization of hydropriming techniques for rice seed invigoration. Seed Science Technology, 34, 507-512.

Flint, S. D., \& Palmblad, I. G. (1978). Germination dimorphism and development flexibility in the ruderal weed Heterotheca grandiflora. Oecologia, 36, 33-43.

Flora Malesiana Symposium. (1989). In P. Baas, K. Kalkman, \& R. Geesink (Eds.), The plant diversity of Malesia: Proceedings of the Flora Malesiana Symposium commemorating Professor Dr. C.G.G.J. van Steenis. Leiden: doi: 10.1007/978-94009-2107-8.

Gashi, B., Abdullai, K., Mata, V., \& Kongjika, E. (2012). Effect of gibberellic acid and potassium nitrate on seed germination of the resurrection plants Ramonda serbica and Ramonda nathaliae. African Journal of Biotechnology, 11(20), 4537-4542.

Gill, D., Magin, G., \& Bertram, E. (2013). Trees and climate change. A guide to the factors that influence species vulnerability and a summary of adaptation options. Fauna and Flora International www.fauna-flora.org.

Gross, K. L., \& Kromer, M. L. (1986). Seed weight effects on growth and reproduction in Oenothera biennis L. Bulletin of the Torrey Botanical Society, $133,252-258$.

Han, C.-Y., Welbaum, G., \& Long, C.-L. (2010). Seed dormancy and germination of Michelia yunnanensis (Magnoliaceae). Scientia Horticulturae, 124, 3-87. https:// doi.org/10.1016/j.scienta.2009.11.021.

Haridasan, K., \& Rao, R. R. (1985). Forest Flora of Meghalaya. Vol I (pp. 168-169). Dehra Dun: Bishen Singh and Mahendrapal Singh.

Hilhorst, H. W. M., \& Karssen, C. M. (1992). Seed dormancy and germination: the role of abscisic acid and gibberellins and the importance of hormone mutants. Plant Growth Regulation, 11, 225-238. https://doi.org/10.1007/BF00024561.

Iralu, V., \& Upadhaya, K. (2016). Dormancy, storability and germination of seeds in Magnolia punduana (Magnoliaceae). Botany, 94, 967-973.

Irwin, S. J., Narasimhan, D., \& Suresh, V. M. (2013). Ecology, distribution and population status of Elaeocarpus venustus Bedd. (Oxalidales: Elaeocarpaceae), a threatened tree species from Agasthiyamalai Biosphere Reserve, southern Western Ghats, India. Journal of Threatened Taxa, 5(9), 4378-4384.

IUCN. (2017). The IUCN Red List of Threatened Species. Version 2017-3. www. iucnredlist.org.

Jain, S. K., \& Rao, R. R. (1983). An Assessment of Threatened Plants of India. Botanical Survey of India (pp 334), Howrah (Calcutta).

Katavic, P. L. (2005). Chemical investigations of the alkaloids from the plants of the family Elaeocarpaceae. PhD thesis. School of Science/Natural Product Discovery (NPD) Faculty of Science, Griffith University.

Khan, M. L. (2004). Effects of seed mass on seedling success in Artocarpus heterophyllus L., a tropical tree species of north-East India. Acta Oecologica, 25, 103-110

Khan, M. L., Bhuyan, P., \& Tripathi, R. S. (2003). Regeneration of Rudraksh (Elaeocarpus ganitrus Roxb.)- a threatened tree species: germination strategies. International Journal of Ecology and Environmental Science, 29, 255-260.

Khan, M. L., \& Shankar, U. (2001). Effect of seed weight, light regime and substratum microsite on germination and seedling growth of Quercus semiserrata Roxb. Tropical Ecology, 42(1), 117-125.

Matakiadis, T., Alboresi, A., Jikumaru, Y., Tatematsu, K., Pichon, O., Renou, J. P., Sotta, B., Kamiya, Y., Nambara, E., \& Troun, H. N. (2009). The Arabidopsis abscisic acid catabolism gene CYP707A2 plays a key role in nitrate control of seed dormancy. Plant Physiology, 149, 949-960.

Matthew, KM. (1999). The Flora of Palni Hills, South India, Part One: Polypetalae, The Rapinat Herbarium (pp. 145-146), Tiruchirapalli.

Murti, S. K. (1993a). Elaeocarpaceae. In B. D. Sharma \& M. Sanjappa (Eds.), Flora of India 3: 562. Calcutta: Botanical Survey of India.

Murti, S. K. (1993b). Family Elaeocarpaceae in India-census and observations. Journal of Economic and Taxonomic Botany, 17(2), 283-296.

Nayar, M. P., \& Sastry, A. R. K. (1990). Red Data Book of Indian Plants. Vol. 3 (p. 114). Calcutta: Botanical Survey of India.

Ng, F. S. P. (1978). Strategies of establishment in Malayan forest trees. In P. B. Tomlinson \& M. H. Zimmermann (Eds.), Tropical Trees as Living Systems (pp. 129-162). Cambridge: Cambridge University Press.

Ng, F. S. P. (1980). Germination ecology of Malaysian woody plants. Malaysian Forester, 43, 406-438.

Nikolaeva, M. G. (1969). Physiology of deep dormancy in seeds. Izdatel'stvo "Nauka," Leningrad. Washington, DC: Translated from Russian by Z. Shapiro, National Science Foundation.

Perez-Garcia, F., Iriondo, J.M., \& Martinez-Laborde, J.B. (1995). Germination behaviour in seeds of Diplotaxis erucoides and D. virgata. Weed Research, 35: 495-502. 
Pipinis, E., Milios, E., Smiri, S. P., \& Gioumousidis, C. (2011). Effect of acid scarification and cold moist stratification on the germination of Cercis siliquastrum L. seeds. Turkish Journal of Agriculture and Forestry, 35, 259-264.

Ramasubbu, R., \& Irudhyaraj, F. D. (2016). Reproductive biology of Elaeocarpus blascoi Weibel, an endemic and endangered tree species of Palni Hills, Western Ghats, India. Current Science, 110(2), 234-240.

Rossetto, M., Gross, C. L., Jones, R., \& Hunter, J. (2004). The impact of clonality on an endangered tree (Elaeocarpus williamsianus) in a fragmented rainforest. Biological Conservation, 117, 33-39.

Saravanan, S., Indra, M., Kamalraj, P., Venkatesh, D. R., \& Muthuchelian, K. (2011). In-situ vegetative propagation of Elaeocarpus venustus Bedd. A threatened endemic tree of Agasthiamalai biosphere reserve, Western Ghats, India. Journal of Bioscience Research, 2(2), 46-49.

Schütz, W. (2000). The importance of seed regeneration strategies for the persistence of species in the changing landscape of Central Europe. Zeitschrift für Ökologie und Naturschutz [R], 9, 73-83.

Singh, B., Ishar, M. P. S., \& Sharma, A. (2013). Estimation of quercetin, an anxiolytic constituent, in Elaeocarpus ganitrus. Journal of Pharmacognosy Phytochemistry, 1(6), 117-121.

Tanaka-Oda, A., Kenzo, T., \& Fukuda, K. (2017). Optimal germination condition by sulfuric acid pretreatment to improve seed germination of Sabina vulgaris Ant. Journal of Forestry Research, 14(4), 251-256.

Thaman, RR, Thomson, LAJ, DeMeo, R, Areki, F, \& Elevitch, CR. (2006). Intsia bijuga (vesi). Species Profiles for Pacific Island Agroforestry (www.traditionaltree.org).

Tripathi, R. S., \& Khan, M. L. (1990). Effects of seed weight and microsite characteristics on germination and seedling fitness in two species of Quercus in a subtropical wet hill forest. Oikos, 57, 289-296.

Upadhaya, K., Mir, A. H., \& Iralu, V. (2017). Reproductive phenology and germination behavior of some important tree species of Northeast India. Proceedings of the National Academy of Science India Section B: Biological Sciences. https://doi.org/10.1007/s40011-017-0841-4.

Upadhaya, K., Pandey, H. N., \& Law, P. S. (2007). The effect of seed mass on germination, seedling survival and growth in Prunus jenkinsii Hook.f. \& Thoms. Turkish Journal of Botany, 31, 31-36.

Vazquez-Yanes, C., \& Perez-Garcia, B. (1976). Notas sobre la morfologia y la anatomia de la testa de las semillas de Ochroma lagopus Sw. Turriolha, 26, 310-311.

Walter, K. S., \& Gillett, H. J. (1998). IUCN Red List of Threatened Plants. Compiled by the World Conservation Monitoring Centre (p. 862). Switzerland and Cambridge: IUCN - the World Conservation Union, Gland.

Wang, L. L., Wang, G. L., \& Liu, D. Y. (2005). Preliminary studies on seed of the endangered Magnolia sieboldii. Journal of Anhui Normal University, 1, 72-75 [In Chinese].

Weibel, R. (1968). Morphologie de l'embryon et de la graine des Elaeocarpus. Candollea, 23, 101-108.

Wiart, C. (2006). Medicinal plants of Asia and the Pacific. Boca Raton: CRC/Taylor \& Francis.

World Conservation Monitoring Centre. (1998). Elaeocarpus prunifolius. The IUCN red list of threatened species 1998: E.T31329A9626982.http://dx.doi.org. https:// doi.org/10.2305/IUCN.UK.1998.RLTS.T31329A9626982.en.

Yang, J. C., Chen, Y. H., \& Lin, T. P. (2001). Effects of stratification on the dormancy and germination of Elaeocarpus japonicus Sieb. \& Zucc. seeds. Taiwan Journal of Forest Science, 16(1), 47-52.

Youssef, S., Lahcen, O., \& Abdelaziz, A. (2012). Breaking seed dormancy in Cupressus atlantica Gaussen, an endemic and threatened coniferous tree in Morocco. Journal of Forestry Research, 23(3), 385-390.

Zuo, J. B. (1994). The analysis of seed characteristic of Michelia yunnanensis. Guizhou Forest Science and Technology, 2, 44-46.

\section{Submit your manuscript to a SpringerOpen ${ }^{\circ}$ journal and benefit from:}

- Convenient online submission

- Rigorous peer review

- Open access: articles freely available online

High visibility within the field

- Retaining the copyright to your article

Submit your next manuscript at $\boldsymbol{\nabla}$ springeropen.com 